\title{
Peningkatan Berpikir Kritis dan Sikap Ilmiah Siswa Kelas X Pada Mata Pelajaran Biologi Melalui Penerapan Model Berbasis Proyek di Kelas X SMA Yayasan Perguruan Keluarga Kota Pematangsiantar
}

\author{
Irwan Lihardo Hulu (1), Dian Perayanti Sinaga (2) \\ Program Studi Pendidikan Biologi Universitas Simalungun \\ irwanliehardo@gmail.com, dianperayanti@gmail.com
}

\begin{abstract}
ABSTRAK
Penelitian ini merupakan penelitian tindakan kelas dengan tujuan untuk mendeskripsikan peningkatan kemampuan berpikir kritis dan sikap ilmiah siswa pada mata pelajaran biologi SMA Swasta Yayasan Perguruan Keluarga Pematangsiantar dengan penerapan model pembelajaran berbasis proyek. Subjek penelitian adalah peserta didik kelas X IPA-1 SMA Swasta Yayasan Perguruan Keluarga yang berjumlah 30 orang. Penelitian dilakukan dalam empat tahap yaitu perencanaan, pelaksanaan tindakan, observasi, dan refleksi. Penelitian Tindakan Kelas (PTK) ini menggunakan model kolaborasi yang mengutamakan kerjasama antara guru, dan peneliti. Instrumen dalam penelitian ini meliputi tes berpikir kritis yang berjumlah 20 soal, dan sikap ilmiah siswa diukur menggunakan lembaran observasi. Sebelum dijadikan alat pengumpul data instrumen yang telah disusun terlebih dahulu diujicobakan untuk mengetahui validitas, reliabilitas, daya beda dan tingkat kesukarannya. Berdasarkan hasil penelitian, rata-rata hasil peningkatan berpikir kritis siswa yakni pada siklus I sebesar 64,50 lalu meningkat pada siklus II dengan nilai rata-rata sebesar 77,50. Pada sikap ilmiah siswa dari setiap pertemuan mengalami peningkatan, yang pada siklus I meningkat menjadi $55 \%$ pada pertemuan 1, lalu meningkat kembali menjadi $60 \%$ pada pertemuan II. Dan pada siklus II sikap ilmiah siswa meningkat menjadi $75 \%$ pertemuan 1 dan meningkat menjadi $85 \%$ pada pertemuan 2 siklus II. Dari hasil penelitian diatas maka dapat disimpulkan bahwa melalui penerapan model pembelajaran berbasis proyek dapat meningkatkan kemampuan berpikir kritis dan sikap ilmiah siswa di kelas X SMA YPK Pematangsiantar.
\end{abstract}

Kata Kunci : Berpikir Kritis, Sikap Ilmiah, $P J B L$

\begin{abstract}
This research is a classroom action research with the aim of describing the improvement of students' critical thinking skills and scientific attitudes in biology subjects at the private high school foundation of Pematangsiantar Family College with the application of project-based learning models. The subjects of the study were 30 students of class X IPA-1 Private Senior High School of the Family College Foundation. The research was conducted in four stages, namely planning, implementing actions, observing and reflecting. This Classroom Action Research (CAR) uses a collaborative model that prioritizes collaboration between teachers and researchers. The instrument in this study included a critical thinking test, amounting to 20 questions, and students' scientific attitudes were measured using observation sheets. Before being used as a data collection tool, the instruments that had been compiled were tested to determine their validity, reliability, differentiation power and level of difficulty. Based on the results of the study, the average result of the improvement in students' critical thinking, namely in the first cycle was 64.50 and then increased in the second cycle with an average value of 77.50 . The scientific attitude of students from each meeting has increased, which in cycle I increased to 55\% at meeting 1, then increased again to $60 \%$ at meeting II. And in cycle II students' scientific attitudes increased to $75 \%$ in meeting 1 and increased to $85 \%$ at meeting 2 in cycle II. From the results of the above research, it can be concluded that through the application of project-based learning models can improve critical thinking skills and scientific attitudes of students in class X SMA YPK Pematangsiantar.
\end{abstract}

Keywords : Critical thingking, Scientific attitude, PJBL 
Hulu, Irwan Lihardo, Sinaga, Dian Perayanti : Peningkatan Berpikir Kritis dan Sikap Ilmiah Siswa Kelas X Pada Mata Pelajaran Biologi Melalui Penerapan Model Berbasis Proyek Kelas X SMA Yayasan Perguruan Keluarga Kota Pematangsiantar

\section{PENDAHULUAN}

\section{Latar Belakang}

Pendidikan merupakan proses yang kompleks, namun kompleksitasnya selalu seiring dengan perkembangan manusia. Melalui pendidikan pula berbagai aspek kehidupan dikembangkan melalui proses belajar dan pembelajaran. Berbagai masalah dalam proses belajar perlu diselaraskan dan distabilkan agar kondisi belajar tercipta sesuai dengan tujuan yang ingin dicapai serta dapat diperoleh seoptimal mungkin. Untuk melengkapi komponen belajar dan pembelajaran di sekolah, sudah seharusnya guru memanfaatkan media atau alat bantu yang mampu merangsang pembelajaran secara efektif dan efisien. Biologi sebagai salah satu bidang studi IPA merupakan suatu ilmu yang besar perannya dalam pendidikan. Belajar biologi sangat bermanfaat bagi kehidupan sehari-hari. Begitu pentingnya peranan biologi maka pemerintah berupaya untuk meningkatkan mutu pengajaran mulai dari tingkat sekolah menengah pertama (SMP) sampai ke perguruan tinggi. Kualitas pendidikan tidak terlepas dari pencapaian hasil atau prestasi belajar siswa, Karena hasil belajar siswa dapat dijadikan tolak ukur untuk menilai apakah pendidikan disuatu sekolah berhasil atau tidak. Pembelajaran biologi sebaiknya dapat divariasikan dengan memberikan contoh permasalahan yang ada dilingkungan sekitar. Materi pokok biologi yang dapat menerapkan permasalahan dilingkungan sekitar adalah pencemaran lingkungan adalah berubahnya tatanan lingkungan oleh kegiatan manusia ataupun proses alam yang menyebabkan kualitas lingkungan turun sampai ketingkat tertentu sehingga lingkungan tidak dapat berfungsi lagi sesuai dengan peruntukannya. Pembelajaran yang dilakukan dengan memunculkan permasalahan diharapkan dapat meningkatkan kemampuan berpikir kritis siswa. Permasalahan yang berkaitan dengan pembelajaran biologi disekolah-sekolah saat ini khususnya di Kota Pematangsiantar adalah masih rendahnya hasil belajar siswa pada mata pelajaran biologi. Keberhasilan proses dan hasil pembelajaran di kelas dipengaruhi oleh beberapa faktor antara lain guru dan siswa (1) rendahnya minat siswa dalam proses belajar; (2) proses pembelajaran berlangsung secara terus menerus dengan menggunakan metode pembelajaran konvensional (ceramah) akibatnya siswa tidak dapat mengembangkan kemampuan berpikir yang siswa miliki; (3) materi pembelajaran belum dikontekskan dengan kehidupan nyata sehingga, siswa sulit untuk menganalisis, menyimpulkan dan mengevaluasi.

\section{Perumusan Masalah}

Rumusan masalah dalam penelitian ini adalah bagaimana penerapan model pembelajaran berbasis proyek dapat meningkatkan kemampuan berpikir kritis dan sikap ilmiah siswa pada mata pelajaran biologi kelas X di SMA Swasta Yayasan Perguruan Keluarga Pematangsiantar.

\section{Tujuan Penelitian}

Berdasarkan rumusan masalah diatas maka tujuan dari penelitian ini adalah Untuk mengetahui penerapan model pembelajaran berbasis proyek terhadap peningkatan kemampuan berpikir kritis dan sikap ilmiah siswa pada mata pelajaran biologi kelas X di SMA Swasta Yayasan Perguruan Keluarga Pematangsiantar.

\section{Manfaat Penelitian}

Pemakaian media pembelajaran dalam proses belajar mengajar dapat membangkitkan minat dan keinginan yang baru, motivasi dan rangsangan kegiatan belajar dan bahkan pengaruhpengaruh psikologis terhadap siswa. Selain itu, media pembelajaran juga dapat membatu guru dalam proses pembelajaran. Salah satu upaya yang dapat dilakukan untuk 
Hulu, Irwan Lihardo, Sinaga, Dian Perayanti : Peningkatan Berpikir Kritis dan Sikap Ilmiah Siswa Kelas X Pada Mata Pelajaran Biologi Melalui Penerapan Model Berbasis Proyek Kelas X SMA Yayasan Perguruan Keluarga Kota Pematangsiantar

mempengaruhi sikap ilmiah, dan hasil belajar tingkat tinggi siswa yaitu dengan menggunakan media pembelajaran dan model Project Based Learning.

\section{METODE PENELITIAN}

Jenis Penelitian

Penelitian Tindakan Kelas (Classroom Action Research) ini menggunakan model kolaborasi yang mengutamakan kerjasama antara guru, dan peneliti. Penelitian Tindakan Kelas (PTK) ini merupakan upaya untuk mengkaji apa yang terjadi dan telah dihasilkan yang berfokus pada upaya untuk mengubah kondisi nyata yang ada sekarang kearah kondisi yang diharapkan. Hasil refleksi digunakan untuk mengambil langkah lebih lanjut dalam upaya mencapai tujuan penelitian. Dengan kata lain refleksi merupakan pengkajian terhadap keberhasilan atau kegagalan terhadap pencapaian tujuan tindakan pembelajaran. Penelitian ini merupakan penelitian analisis deskriptif-kuantitatif yang bertujuan untuk memperbaiki dan mencari solusi dari persoalan nyata dan praktis dalam meningkatkan mutu pembelajaran di kelas. Penelitian ini dilakukan dalam 2 siklus yaitu siklus I dan siklus II. Siklus I terdiri dari 1 pertemuan, siklus II terdiri dari 1 pertemuan. Penelitian ini terdiri dari empat tahapan yaitu perencanaan (planning), pelaksanaan (acting), pengamatan (observing) dan refleksi (reflecting). Analisis penelitian ini adalah analisis deskriptif kuantitafif dan kualitatif dimana dalam penelitian ini selain penyajian hasil berupa data maupun angka peneliti juga mendeskripsika hasil penelitian yakni dengan membuat analisisnya dengan menerapkan model penelitian Project Based Learning. Dalam penelitian ini data yang dikumpulkan adalah data hasil berpikir kritis siswa yang menggunakan soal sejumlah 20 soal.

\section{Teknik Analisis Data}

Teknik analisis data yang digunakan dalam penelitian ini adalah teknik analisis berupa deskriptif dan analisis inferensial. Teknik analisis deskriftif dan analisis inferensial. Teknik analisis deskriptif dimaksudkan untuk mendeskripsikan data penelitian meliputi mean, median, modus, varians dan standar deviasi. Data yang diperoleh selanjutnya disajikan dalam bentuk tabel distribusi frekuensi menggunakan aturan sturges dan dalam bentuk histogram. Analisis statistik inferensial dilakukan untuk menguji hipotesis, sebelum pengujian hipotesis, terlebih dahulu dilakukan uji prasyarat terhadap data yang dikumpulkan yaitu dengan menggunakan uji normalitas dan homogenitas. Uji normalitas dimaksudkan untuk menguji apakah data sampel yang diperoleh dari populasi memiliki sebaran yang berdistribusi nomal. Uji normalitas dilakukan dengan uji lilifors atau dengan pendekatan kolmograv-smirnov menggunakan program SPSS 22.0. Sedangkan uji homogenitas dimaksudkan untuk menguji apakah kelompok-kelompok yang membentuk sampel berasal dari populasi yang sama, artinya penyebarannya dalam populasi bersifat homogeny. Uji homogenitas data dilakukan dengan uji burlett atau menggunakan pendekatan Levene's Test dengan bantuan program SPSS 22.0.Data hasil observasi pada penelitian ini merupakan pengamatan terhadap siswa selama proses pembelajaran mengacu pada indikator sikap ilmiah siswa yang meliputi kemampuan siswa mencari pernyataan yang jelas dari setiap pertanyaan, kemampuan siswa mencari alasan, siswa berusaha mengetahui informasi dengan baik, siswa memperhatikan situasi dan kondisi secara keseluruhan, siswa bersikap dan berpikir terbuka, siswa mengambil posisi ketika ada bukti yang cukup untuk melakukan sesuatu, siswa mencari penjelasan sebanyak mungkin apabila memungkinkan, dan siswa bersikap secara sistimatis dan teratur dengan bagian-bagian dari keseluruhan masalah. Siswa mendapat skor antara 4 sampai dengan 1 untuk setiap indikator. Metode observasi dalam penelitian ini digunakan untuk memperoleh data tentang sikap ilmiah siswa terhadap materi yang diajarkan oleh guru. Lembar observasi yang digunakan berdasarkan skala nilai (rating 
Hulu, Irwan Lihardo, Sinaga, Dian Perayanti : Peningkatan Berpikir Kritis dan Sikap Ilmiah Siswa Kelas X Pada Mata Pelajaran Biologi Melalui Penerapan Model Berbasis Proyek Kelas X SMA Yayasan Perguruan Keluarga Kota Pematangsiantar

scale). Lembar observasi akan diisi oleh observer dengan cara memberi tanda checklist $(\sqrt{ })$ pada pilihan yang tepat sesuai dengan pengamatannya. Penelitian ini menggunakan pedoman observasi Rating Scale atau skala penilaian dengan berskala empat. Mengacu pada analisis data hasil observasi dan analisis data hasil tes, maka kemampuan berpikir siswa pada penelitian ini diperoleh dengan menghitung nilai dari gabungan hasil observasi dengan hasil tes masingmasing siswa dengan bobot $40 \%$ untuk hasil tes dan $60 \%$ untuk hasil observasi berdasarkan pertimbangan dari expert judgement. Glaser (Fisher, 2009: 3).

\section{HASIL}

Berdasarkan hasil penelitian yang telah dilakukan, menunjukkan bahwa kemapuan berpikir siswa menerapkan model Project Based Learning (PjBL) mengalami peningkatan. Hasil perbandingan tersebut disajikan pada tabel berikut ini :

Tabel 1 Deskripsi Data Tes Kemampuan Berpikir Kritis

\begin{tabular}{|c|c|c|c|c|c|}
\hline Siklus & Mean & Median & $\begin{array}{c}\text { Standart } \\
\text { Deviasi }\end{array}$ & Maksimum & Minimum \\
\hline Siklus I & 64,50 & 65,00 & 4,97 & 70 & 50 \\
\hline Siklus II & 79,50 & 80,00 & 3,30 & 85 & 70 \\
\hline
\end{tabular}

Berdasarkan Tabel diatas dapat dilihat bahwa rata-rata hasil berpikir kritis siswa pada siklus I adalah 64,31 dengan standar deviasi 64,50; nilai minimum yang diperoleh adalah 50; dan nilai maksimum yang diperoleh 70 . Sedangkan pada siklus II sesudah diberikan model pembelajaran berbasis proyek adalah 79,50 dengan standar deviasi 3,30; nilai minimum yang diperoleh adalah 70; dan nilai maksimum yang diperoleh 80. Nilai dari Siklus I dan II tersebut kemudian dihitung tingkat kenaikan hasil belajarnya untuk mengetahui efektifitas pembelajaran dengan model pembelajaran Project Based Learning. Rumus yang digunakan adalah rumus $\mathrm{N}$-gain ternormalisasi. Berdasarkan hasil perhitungan $\mathrm{N}$-gain ternormalisasi diperoleh rata-rata kenaikan hasil belajar dari 30 orang siswa adalah 0,75 . Menurut kriteria nilai tersebut menunjukkan bahwa kenaikan kemampuan berpikir kritis siswa dalam kategori "sedang".Berikut disajikan dalam bentuk diagram perbandingan kemampuan berpikir kritis siswa dari siklus I hingga siklus II.

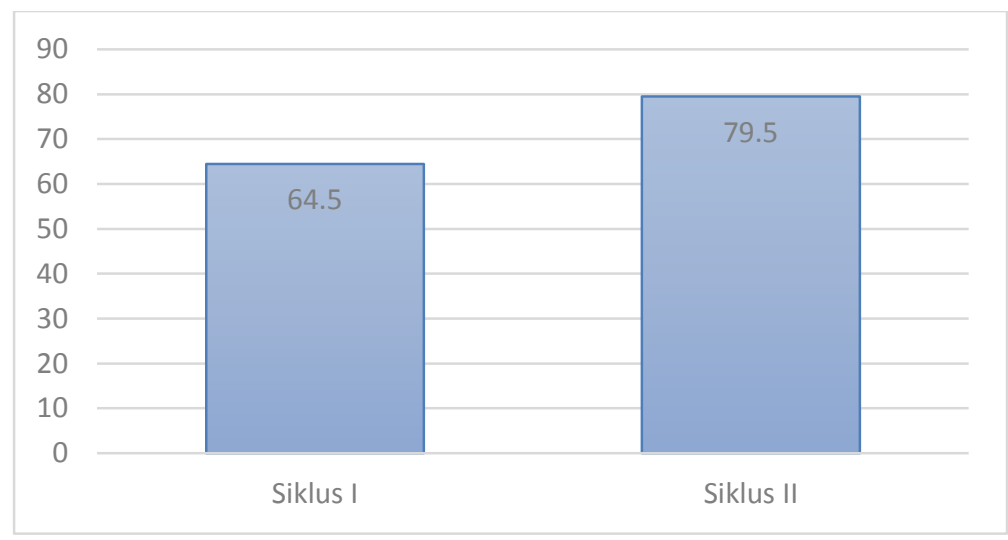

Gambar 1 Diagram Perbandingan Kemampuan Berpikir Kritis siswa Siklus I dan II 
Hulu, Irwan Lihardo, Sinaga, Dian Perayanti : Peningkatan Berpikir Kritis dan Sikap Ilmiah Siswa Kelas X Pada Mata Pelajaran Biologi Melalui Penerapan Model Berbasis Proyek Kelas X SMA Yayasan Perguruan Keluarga Kota Pematangsiantar

Berdasarkan hasil analisis data pada sikap ilmiah siswa dengan penerapan model pembelajaran Project Based Learning (PjBL) juga mengalami peningkatan. Pada pertemuan 1 siklus I sebesar 55\% lalu meningkat pada pertemuan 2 menjadi $60 \%$. Kemudian dilakukan tindakan siklus II yang berhasil meningkatkan sikap ilmiah siswa pada pertemuan 1 siklus II sebesar 75\% lalu meningkat lagi pada pertemuan 2 menjadi $85 \%$. Peningkatan tersebut menunjukkan bahwa model pembelajaran berbasis proyek dapat meningkatkan sikap ilmiah siswa di kelas X SMA YPK Kota Pematangsiantar.I

Tabel 2 Perbandingan Sikap Ilmiah Siswa Pada Siklus I dan Siklus II.

\begin{tabular}{|l|l|l|}
\hline \multicolumn{1}{|c|}{ Siklus } & \multicolumn{2}{c|}{ Sikap Ilmiah Siswa } \\
\hline \multirow{2}{*}{ Siklus I } & Pertemuan I & $55 \%$ \\
\cline { 2 - 3 } & Pertemuan II & $60 \%$ \\
\hline \multirow{2}{*}{ Siklus II } & Pertemuan I & $75 \%$ \\
\cline { 2 - 3 } & Pertemuan II & $85 \%$ \\
\hline
\end{tabular}

Berdasarkan tabel perbandingan sikap ilmiah siswa di kelas X SMA YPK Kota Pematangsiantar dapat dilihat bahwa sikap ilmiah siswa setiap siklusnya mengalami peningkatan.

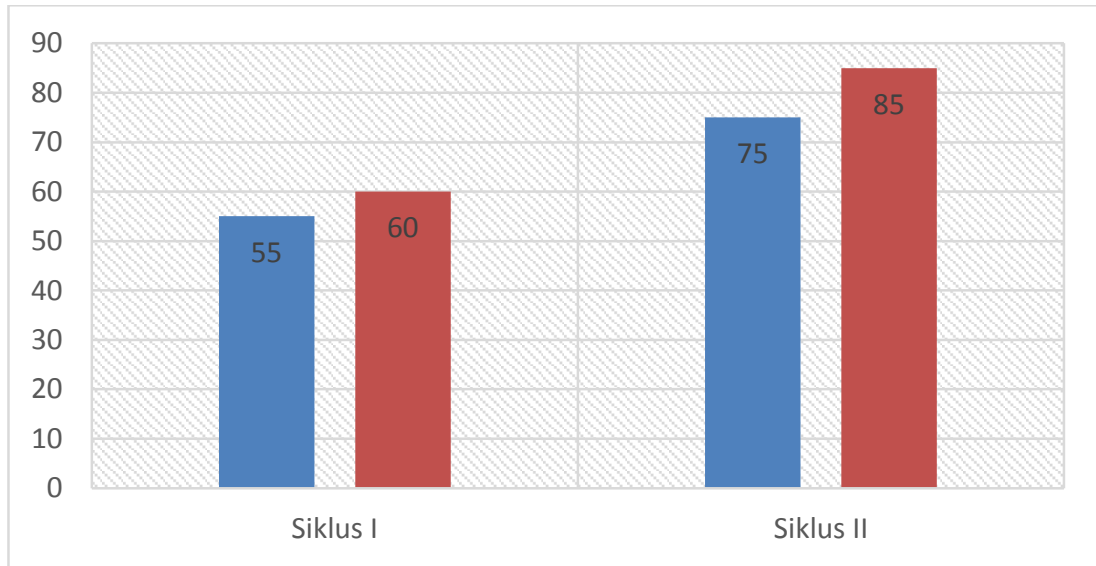

Gambar 2 Diagram perbandingan sikap ilmiah siswa di kelas X SMA YPK Kota Pematangsiantar

Analisis data hasil penelitian siklus I dan II terlihat adanya peningkatan persentase pada variabel sikap ilmiah siswa menggunakan model pembelajaran berbasis proyek. Hal ini menunjukkan bahwa dengan menggunakan model pembelajaran berbasis proyek dapat meningkatkan sikap ilmiah siswa.

\section{PEMBAHASAN}

Berdasarkan hasil setelah diberikannya tindakan perbaikan dalam kegiatan pembelajaran yang diberikan pada siklus I dan siklus II, dapat diketahui bahwa penerapan model pembelajaran berbasis proyek dapat meningkatkan berpikir kritis dan sikap ilmiah siswa. Berdasarkan hasil rata-rata berpikir kritis siswa siklus I $(64,50)$ apabila ditinjau dari kriteria ketercapaiannya masih belum memenuhi kriteria keberhasilan. Hal ini dikarenakan pada saat kegiatan pembelajaran masih banyak siswa yang tidak kosentrasi sehingga pada saat proses pembelajaran masih banyak siswa yang tidak faham. Pada Siklus II meningkat dengan ratarata 79,50, sehingga pada siklus II mampu memenuhi kriteria keberhasilan yang telah ditentukan. Pembelajaran menggunakan Project Based Learning (PjBL) menjadi 
Hulu, Irwan Lihardo, Sinaga, Dian Perayanti : Peningkatan Berpikir Kritis dan Sikap Ilmiah Siswa Kelas X Pada Mata Pelajaran Biologi Melalui Penerapan Model Berbasis Proyek Kelas X SMA Yayasan Perguruan Keluarga Kota Pematangsiantar

pengalaman bermakna karena memungkinkan siswa menguasai suatu konsep, memecahkan suatu masalah melalui penyelesaian proyek dan memberi kesempatan memunculkan ide-ide atau gagasan yang sekreatif mungkin untuk menyelesaikan masalah tersebut. Sedangkan pada sikap ilmiah siswa pada pembelajaran dengan menerapkan model pembelajaran berbasis masalah yang diterapkan mendorong siswa untuk terlibat lebih kreatif dalam memecahkan masalah-masalah yang tiba-tiba terjadi dan mendorong siswa untuk mampu mencari alternatif-alternatif jawaban dari permasalahan tersebut. Berdasarkan hasil observasi yang telah dilakukan selama kegiatan pembelajaran berlangsung pada siklus I yang terdiri dari 2 pertemuan rata-rata persentase sikap ilmiah siswa yakni 55\%. Peningkatan pada siklus I masih terjadi beberapa kendala yakni masih banyaknya siswa yang kemampuan dalam memecahkan masalah yang sebelumnya tidak terfikirkan. Pada peningkatan sikap ilmiah siswa pada siklus I ini belum mencapai keberhasilan siswa yang telah ditetapkan. Sehingga untuk meningkatkan sikap ilmiah siswa agar mencapai keberhasilan dilakukan perbaikan pada siklus II. Setelah dilakukannya perbaikan tindakan pada siklus II peningkatan kreatifitas pada siklus I meningkat menjadi $85 \%$ pada siklus II. Pada siklus II kemampuan siswa dalam mengembangkan sikap ilmiah untuk menciptakan pemecahan masalah yang tidak terfikirkan dan mencari solusinya. Dalam pembelajaran Project Based Learning (PjBL) ini siswa tak hanya dituntut untuk mampu mengungkapkan gagasannya, namun siswa juga dituntut untuk mampu memecahkan masalah melalui pemberian proyek sehingga sikap ilmiah siswa dalam berpikir meningkat.

\section{KESIMPULAN}

Berdasarkan hasil penelitian dan pembahasan, maka dapat disimpulkan bahwa dengan penerapan model pembelajaran berbasis proyek dapat meningkatkan berpikir kritis dan sikap ilmiah siswa kelas X SMA YPK Pematangsiantar. Hal ini terlihat pada rata-rata hasil peningkatan berpikir kritis siswa yakni pada siklus I sebesar 64,50 lalu meningkat pada siklus II dengan nilai rata-rata sebesar 77,50. Pada sikap ilmiah siswa dari setiap pertemuan mengalami peningkatan, yang pada siklus I meningkat menjadi $55 \%$ pada pertemuan 1 , lalu meningkat kembali menjadi 60\% pada pertemuan II. Dan pada siklus II sikap ilmiah siswa meningkat menjadi $75 \%$ pertemuan 1 dan meningkat menjadi $85 \%$ pada pertemuan 2 siklus II. Dari hasil penelitian diatas maka dapat disimpulkan bahwa melalui penerapan model pembelajaran berbasis proyek dapat meningkatkan kemampuan berpikir kritis dan sikap ilmiah siswa di kelas X SMA YPK Pematangsiantar.

\section{DAFTAR PUSTAKA}

Anwar, H. 2015. Penilaian Sikap Ilmiah dalam Pembelajaran Sains. Jurnal Pelangi Ilmu, 2 (5): 103-114.

Aunurrahman. 2012. Belajar dan Pembelajaran. Bandung: Alfabeta.

Fakhruddin, Eprina, E,. dan Syahril. 2011. Sikap Ilmiah Siswa dalam Pembelajaran Fisika dengan Penggunaan Media Komputer Melalui Model Kooperatif Tipe STAD pada Siswa Kelas X3 SMA Negeri I Bangkinang Barat. Jurnal Geliga Sains, 4 (1): 18-22.

Hosnan. 2014. Pendekatan Saintifik dan Kontekstual dalam Pembelajaran Abad 21. Bogor: Ghalia Indonesia.

Hung, C.M., Hwang, G.-J., \& Huang, I. (2014). A Project-Based Digital Storytelling Approach For Improving Students' Learning Motivation, Problem-Solving Competence And Learning Achievement. Educational Technology \& Society Journal, 15 (4): 368-379.

Lufri. 2014. Strategi Pembelajaran Biologi Teori, Praktek, dan Penelitian. Padang: Negeri Padang University Press. 
Hulu, Irwan Lihardo, Sinaga, Dian Perayanti : Peningkatan Berpikir Kritis dan Sikap Ilmiah Siswa Kelas X Pada Mata Pelajaran Biologi Melalui Penerapan Model Berbasis Proyek Kelas X SMA Yayasan Perguruan Keluarga Kota Pematangsiantar

Marlinda, N. L. P. M. 2013. Pengaruh Model Pembelajaran Berbasis Proyek Terhadap Kemampuan Berpikir Kreatif dan Kinerja Ilmiah Siswa. Tesis. Bali: Program Pascasarjana Undiksha.

Munawaroh, A., Christijanti, W., dan Supriyanto. 2013. Pengaruh Model Pembelajaran Berbasis Proyek Untuk Meningkatkan Hasil Belajar Sistem Pencernaan SMP. Unnes Journal Of Biology Education, 2 (1): 91-98

Ngalimun. 2013. Strategi dan Model Pembelajaran. Yogyakarta: Aswaja Pressindo.

Purwanto. 2013. Evaluasi Hasil Belajar. Yogyakarta: Pustaka Pelajar.

Purworini, S. E. 2016. Pembelajaran Berbasis Proyek sebagai Upaya Mengembangkan Habit of Mind Studi Kasus di SMP Nasional KPS Balikpapan. Jurnal Pendidikan Inovatif, 1 (2): 17-19.

Sihotang. 2014. pengaruh Pembelajaran berbasis proyek terhadap hasil belajar biologi tingkat tinggi peserta didik kelas XI SMA Negeri 2 Kisaran. Tesis.

Yalcin, A., Turgut, U., dan Buyukkasap, E.2017. The Effect Of Project Based Learning On Science Undergraduates' Learning Of Electricity, Attitude Towards Physics and Scientific Process Skills. International Online Journal Of Educational Sciences, 1 (1): 81-105

\begin{tabular}{|l|l|l|l|}
\hline Accepted Date & Revised Date & Decided Date & Accepted to Publish \\
\hline 19 November 2020 & 20 November 2020 & 27 November 2020 & Ya \\
\hline
\end{tabular}

